\title{
KARAKTERISTIK BANGUNAN HIJAU PADA RUMAH SUSUN UMUM DI DAERAH BERIKLIM TROPIS LEMBAB
}

\author{
Putri Herlia Pramitasari \\ Dosen Prodi Arsitektur, Fak. Teknik Sipil dan Perencanaan, ITN Malang \\ e-mail: putri herlia@lecturer.itn.ac.id \\ Suryo Tri Harjanto \\ Dosen Prodi Arsitektur, Fak. Teknik Sipil dan Perencanaan, ITN Malang \\ e-mail: totosuryo@lecturer.itn.ac.id \\ Muhammad Nelza Mulki lqbal \\ Dosen Prodi Arsitektur, Fak. Teknik Sipil dan Perencanaan, ITN Malang \\ e-mail: nelzamigbal@lecturer.itn.ac.id
}

\begin{abstract}
ABSTRAK
Saat ini, desain bangunan vertikal telah menjadi kebutuhan dalam pembangunan hunian rumah susun hingga masa mendatang. Konsep bangunan hijau diperlukan sebagai strategi penerapan pembangunan berkelanjutan yang efisien energi. Kajian ini dimaksudkan untuk mengetahui karakteristik bangunan hijau pada rumah susun umum, khususnya di daerah beriklim tropis lembab. Metodologi penelitian kualitatif digunakan sebagai pendekatan penelitian kali ini melalui metode deskriptif analisis dengan mengambil objek studi bangunan Rumah Susun Muharto, Rusunawa Buring 1, dan Rusunawa Buring 2, Kota Malang. Variabel yang dikaji, diantaranya efisiensi terhadap tapak, efisiensi penggunaan energi, konservasi air, efisiensi penggunaan material, aspek kesehatan dan kenyamanan ruang, serta sistem kontrol dan tata kelola lingkungan bangunan. Hasil penelitian didapatkan bahwa konsep desain bangunan hijau belum diterapkan secara optimal pada objek studi penelitian. Strategi penerapan bangunan hijau pada bangunan rumah susun umum harus dikembangkan dari standard atau pedoman bangunan hijau didukung legalitas dan kebijakan pemerintah, serta diaplikasikan dalam seluruh siklus hidup bangunan sehingga terpenuhi prinsip arsitektur berkelanjutan.
\end{abstract}

\section{Kata kunci : Bangunan Hijau, Rumah Susun Umum, Iklim Tropis Lembab}

\begin{abstract}
At present, vertical building designs have become a necessity in the construction of flats until the future. Green building concept is needed as a strategy for implementing energy efficient sustainable development. This study is intended to determine the characteristics of green buildings in public flats, especially in humid tropical climates. The qualitative research methodology is used as the research approach this time through the descriptive analysis method by taking the object of the study of the building of the Muharto Flats, Rusunawa Buring 1, and Rusunawa Buring 2, Malang City. The variables studied include site efficiency, energy use efficiency, water conservation, material use efficiency, space health and comfort
\end{abstract}


aspects, as well as a building's environmental management and control system. The results showed that the green building design concept has not been optimally applied to the object of research study. The strategy of implementing green buildings in public flats must be developed from standards or guidelines for green buildings supported by legality and government policies, and applied throughout the building life cycle so that the principles of sustainable architecture are met.

\section{Keywords : Green Building, Public Flats, Humid Tropical Climate}

\section{PENDAHULUAN}

Pembangunan rumah susun umum di Indonesia menjadi kebutuhan signifikan pada saat ini hingga era mendatang, mengingat kebutuhan hunian khususnya masyarakat menengah ke bawah semakin meningkat, sementara lahan yang tersedia semakin terbatas. Kota Malang menjadikan pembangunan rumah susun umum sebagai prioritas utama dalam pemenuhan kebutuhan hunian penduduk hingga beberapa tahun ke depan.

Penerapan bangunan hijau pada rancang bangun rumah susun umum menjadi arahan kebijakan pembangunan dari Pemerintah sebagai strategi keberlanjutan pembangunan kawasan dan lingkungan. Minimnya pengetahuan dan sumber daya tentang efisiensi energi dan bangunan hijau menjadikan masyarakat belum banyak tergerak untuk menerapkan prinsipprinsip bangunan hijau pada daerah beriklim tropis lembab.

Oleh karena itu, diperlukan arahan penerapan prinsip bangunan hijau pada bangunan rumah susun umum di daerah beriklim tropis lembab agar dapat terwujud hunian rumah susun umum yang sehat, nyaman termal, dan layak huni bagi pengguna, serta memiliki ketahanan bangunan lama.

\section{TINJAUAN PUSTAKA}

Arsitektur hijau merupakan konsep arsitektur melalui pemanfaatan sumber energi dan sumber daya alam secara optimal dan efisien untuk meminimalkan dampak negatif terhadap lingkungan alam dan manusia (Sudarwani, M. M. 2012). Kriteria konsep arsitektur hijau diantaranya, performa bangunan tinggi, ramah lingkungan, berkelanjutan, tanggap iklim, memberikan dampak positif untuk kesehatan pengguna dan lingkungan, serta desain estetis dan fungsional.

Sementara itu, bangunan hijau yaitu konsep bangunan berkelanjutan dengan prinsip hemat energi pada seluruh siklus hidup bangunan (penentuan tapak, desain, konstruksi, operasional, pemeliharaan, hingga pembongkaran), dimana harus berdampak positif pada lingkungan, sosial, 
dan ekonomi (Sudarwani, M. M. 2012). Pemenuhan kriteria bangunan hijau, yaitu (Sudarwani, M. M. 2012):

a. Efisiensi energi

Berupa desain dan/ atau teknologi bangunan pasif.

b. Efisiensi air

Berupa konservasi air.

C. Efisiensi material

Berupa pemanfaatan reuse, reduce, dan recycle material, serta produksi material lokal.

d. Peningkatan kualitas lingkungan

Berpengaruh terhadap kenyamanan, kesehatan, dan produktivitas pengguna.

e. Optimasi operasional dan pemeliharaan

Berpengaruh terhadap peningkatan kualitas udara dalam ruangan.

f. Pengurangan sampah

Berupa konversi limbah dan air limbah.

g. Efisiensi biaya dan manfaat

Berupa efisiensi utilitas.

h. Penetapan peraturan

Berupa peraturan standard, kode, dan sistem peringkat bangunan hijau.

Sementara itu, Green Building Council Indonesia (2016) telah menetapkan enam (6) kriteria bangunan hijau untuk bangunan yang sudah terbangun, diantaranya:

a. Pemilihan dan pengembangan tapak

Meliputi kebijakan atau peraturan manajemen tapak, kebijakan pengurangan pemakaian kendaraan bermotor, aksesibilitas pejalan kaki dan pengadaan fasilitas umum, lansekap tapak, dampak heat island, manajemen air tanah, dan peningkatan kualitas hidup masyarakat di sekitar bangunan.

b. Efisiensi dan konservasi energi

Meliputi kebijakan atau peraturan dan perencanaan manajemen energi, kinerja energi bangunan, optimasi kinerja efisiensi energi bangunan, pengecekan penggunaan peralatan elektronik, kinerja 
sistem energi, sistem kontrol dan monitoring energi, sistem pengoperasian dan pemeliharaan sumber energi, sumber energi terbarukan, serta emisi energi.

c. Konservasi air

Meliputi kebijakan atau peraturan manajemen air, penyediaan submeter konsumsi air, sistem kontrol penggunaan dan pemeliharaan, efisiensi konsumsi air bersih, kualitas sumber air bersih, penggunaan air daur ulang, penggunaan air portable, pengurangan penggunaan sumur dalam, serta penggunaan kran air.

d. Sumber daya dan siklus material

Meliputi penggunaan refrigerant non-CFC pada AC, kebijakan penggunaan material ramah lingkungan, kebijakan atau peraturan manajemen pengelolaan sampah, prosedur penanganan sampah, manajemen pengelolaan limbah berbahaya (B3), serta pemanfaatan barang bekas.

e. Kenyamanan dan kesehatan ruang dalam

Meliputi upaya meminimalisir aktivitas merokok dalam bangunan, sistem sirkulasi udara, monitoring gas $\mathrm{CO}$ dan $\mathrm{CO}_{2}$ dalam ruang, pengukuran sumber pencemar udara dalam ruang, kenyamanan termal, kenyamanan visual, tingkat kebisingan, dan survei kenyamanan pengguna bangunan.

f. Manajemen lingkungan bangunan

Meliputi kebijakan atau peraturan operasional dan pemeliharaan bangunan, utilitas, sampah, inovasi peningkatan kualitas dan manajemen bangunan, desain bangunan, serta pelaksanaan pelatihan operasional dan pemeliharaan bangunan hijau.

Arsitektur berkelanjutan sendiri sangat diperlukan bagi para arsitek agar lebih peka terhadap segala aspek lingkungan dalam desain yang nantinya berpengaruh terhadap seluruh siklus hidup bangunan. (Tanuwidjaja, G. 2011). Aspek-aspek penting dalam kerangka arsitektur berkelanjutan, diantaranya proses desain, konstruksi, operasional, pemeliharaan, tapak, air, material bangunan, kenyamanan termal, kesadaran masyarakat, energi, serta inovasi (Tanuwidjaja, G. 2011). Sudarwani, M. M. (2012) juga menekankan bahwa konsep arsitektur berkelanjutan terkait erat dengan efisiensi energi, efisiensi lahan, material, serta manajemen limbah.

Dengan demikian, konsep bangunan hijau dapat disimpulkan memenuhi prinsip-prinsip arsitektur berkelanjutan. Kajian kali ini akan 
dititikberatkan pada pengembangan konsep bangunan hijau pada rumah susun umum di Indonesia sebagai daerah beriklim tropis lembab.

\section{METODE PENELITIAN}

Metode penelitian kualitatif deskriptif analisis digunakan dalam penelitian ini melalui teknik pengumpulan data berupa data primer melalui observasi lapangan, survei (wawancara dan kuesioner), dan data sekunder. Metode pengumpulan data primer didapatkan melalui observasi lapangan, kuesioner, dan wawancara; serta pengumpulan data sekunder melalui kajian litetarur, artikel ilmiah berupa jurnal atau prosiding, buku teks, peraturan pemerintah, SNI, dan dokumen salinan gambar kerja objek studi penelitian. Metode analisis development dijabarkan dalam bentuk uraian deskriptif dari data yang terkumpul dengan tidak mengutamakan angka dan statistik.

Variabel penelitian yang dikaji, yaitu aspek efisiensi lahan, energi, air, material, kualitas kenyamanan dan kesehatan ruang dalam bangunan, serta manajemen lingkungan bangunan pada objek studi penelitian terhadap kriteria desain bangunan hijau. Instrumen penelitian yang digunakan, diantaranya handphone dan alat ukur meteran.

Objek studi penelitian, yaitu Rusunawa Buring 1 (Jl. Mayjend Sungkono, Buring) dan Rusunawa Buring 2 (Jl. Simpang Gading, Buring) di Kecamatan Kedungkandang, Kota Malang, serta Rumah Susun Muharto Kuto Bedah, Kotalama, Kecamatan Kedungkandang, Kota Malang.
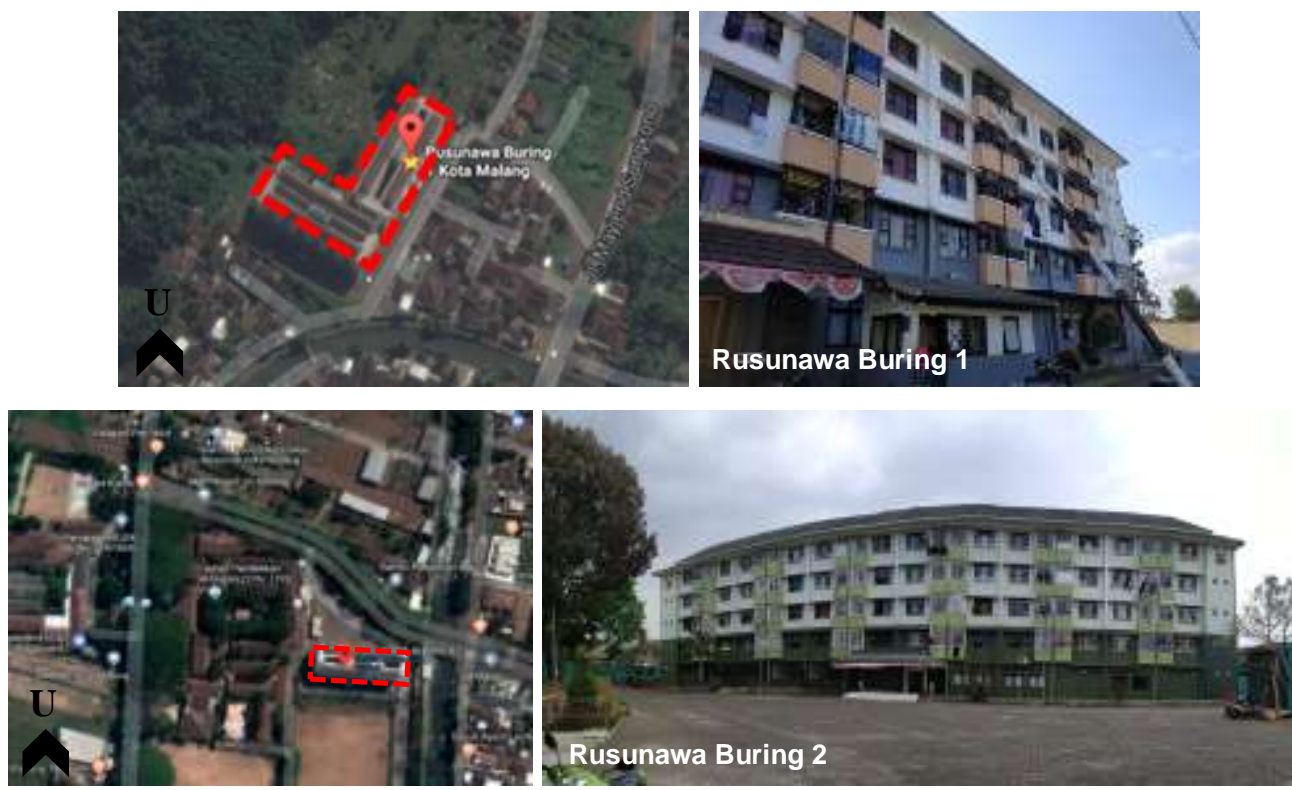

Gambar 1. 
Objek Studi Rusunawa Buring 1 dan 2, Kota Malang.

Sumber: Google maps dan dokumentasi penulis, 2019
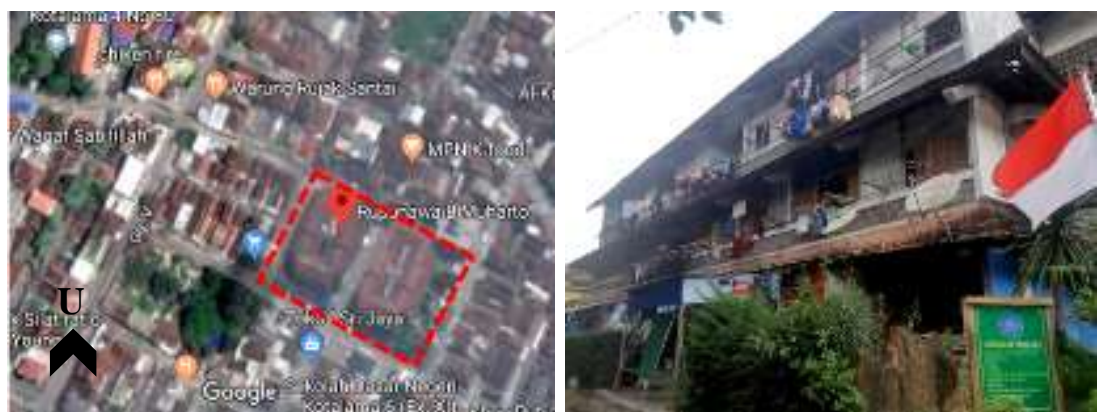

Gambar 2.

Objek Studi Rumah Susun Muharto, Kota Malang.

Sumber: Google maps dan dokumentasi penulis, 2019

\section{HASIL DAN PEMBAHASAN}

Karakteristik banggunan hijau pada objek studi penelitian selengkapanya dapat dijabarkan sebagai berikut.

\section{a. Efisiensi Lahan}

Pengelolaan desain tapak pada Rusunawa Buring 1 dirancang dan terawat dengan cukup baik. Hal ini dapat dilihat dari pengadaan fasilitas publik berupa ruang terbuka berupa taman dan area bermain anak sebagaimana dapat dilihat pada Gambar 3.
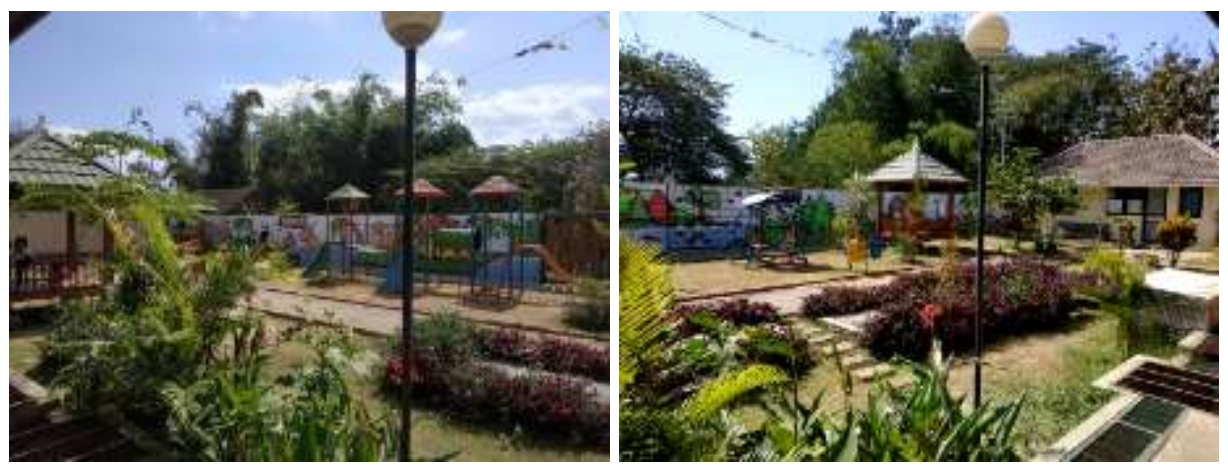

Gambar 3.

Taman Bermain Anak pada Rusunawa Buring 1, Kota Malang Sumber: Dokumentasi penulis, 2019

Pengadaan fasilitas berupa area parkir kendaraan motor dan mobil, serta pemanfaatan railing sebagai area penghijauan di sepanjang koridor lantai atas unit hunian Rusunawa Buring 1 Blok B sebagaimana dapat dilihat pada Gambar 4, turut menjadi salah satu upaya dalam optimasi desain 
elemen lansekap sebagai bentuk pencegahan pemanasan dalam bangunan dan menambah kadar oksigen pada lingkungan bangunan.

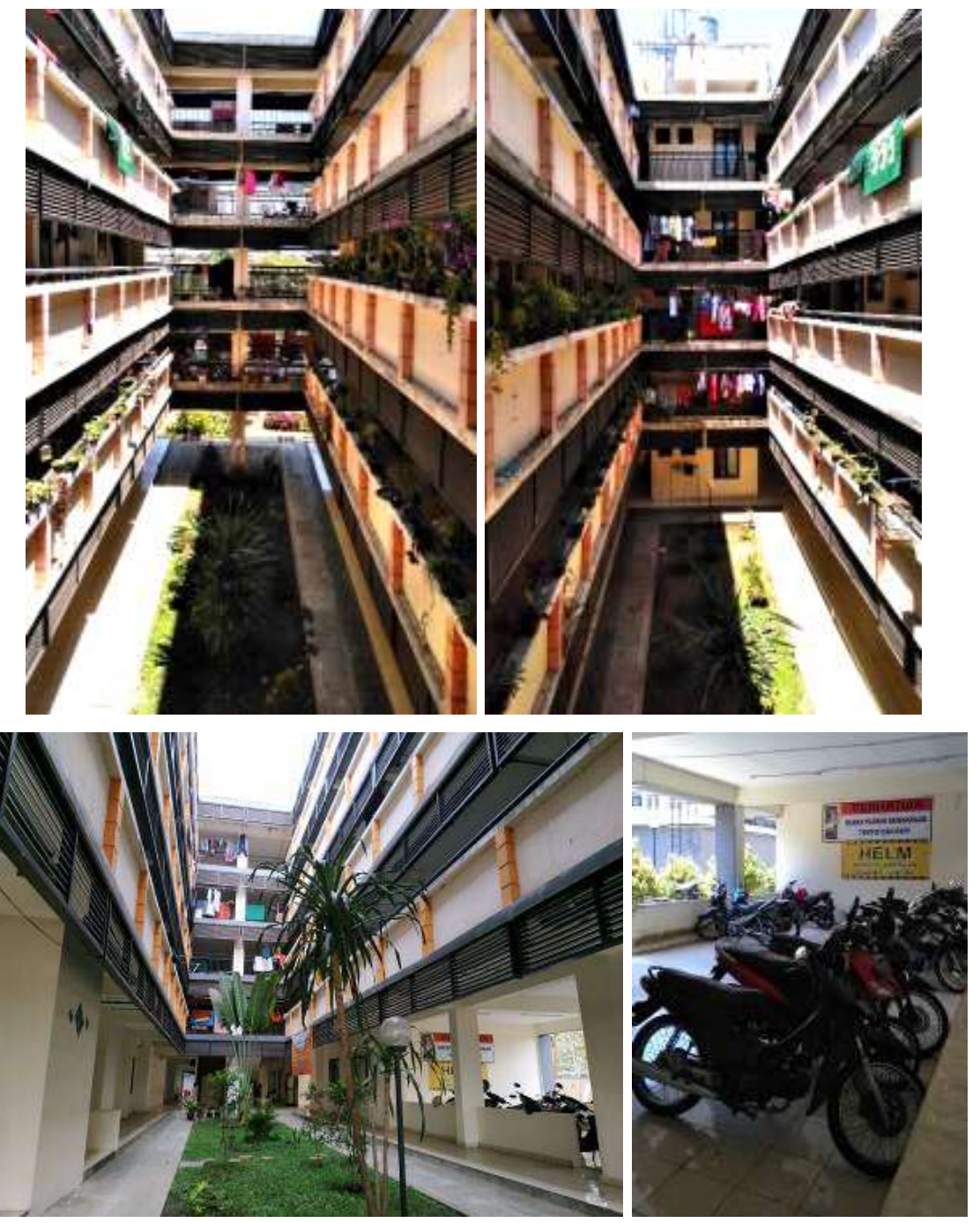

Gambar 4.

Pemanfaatan Ruang Terbuka pada Rusunawa Buring 1, Kota Malang Sumber: Dokumentasi penulis, 2019

Olahan desain tapak pada Rusunawa Buring 2 dirancang dan tertata lebih baik dan bersih dibandingkan dengan Rusunawa Buring 1, Kota Malang sebagaimana terlihat pada Gambar 5. Fasilitas ruang terbuka hijau, area bermain anak, area parkir kendaraan roda dua dan roda empat juga diwadahi sesuai kebutuhan pengguna. Namun, pemanfaatan koridor sebagai area penghijauan belum ditemui pada Rusunawa Buring 2. Fasilitas 
area parkir yang luas turut dimanfaatkan sebagai sarana olahraga bagi pengguna. Taman lansia juga diwadahi pada Rusunawa Buring 2 untuk mengakomodir sarana olahraga bagi para lansia.
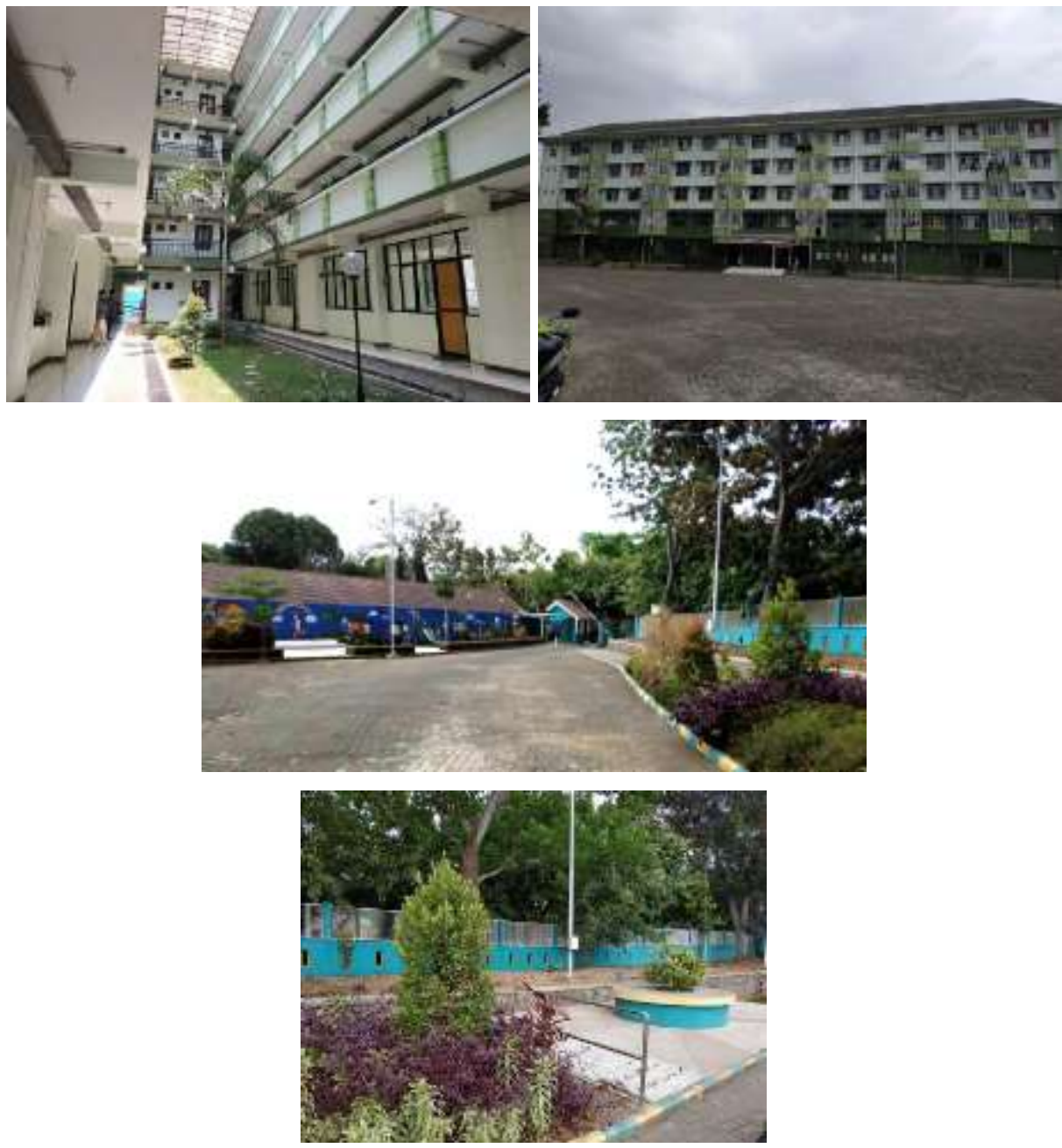

Gambar 5.

Fasilitas Ruang Terbuka pada Rusunawa Buring 2, Kota Malang

Sumber: Dokumentasi penulis, 2019

Sementara pada Rumah Susun Muharto terdapat Ruang Terbuka Hijau (RTH) pada lantai dasar, namun kurang terawat dan terkelola dengan baik. Area parkir kendaraan bermotor terletak di lantai dasar dengan memanfaatkan area tengah lantai dasar yang biasa digunakan untuk area berkumpul, sedangkan area parkir mobil di sisi Timur tapak; dimana area parkir kendaraan tidak didesain sesuai kebutuhan kapasitas pengguna sehingga tidak terfasilitasi secara optimal. 
Sarana transportasi vertikal berupa ramp untuk warga diffable dan pengadaan fasilitas pos kesehatan dan dapur bersama belum terwadahi di Rusunawa Buring 1 dan 2. Sementara itu, kios usaha, pos kesehatan, kamar mandi dan dapur pada tiap unit hunian, serta unit hunian dan ramp untuk warga penderita cacat (diffable) belum terwadahi pada Rumah Susun Muharto. Musholla dan kantor pengelola pun memanfaatkan ruang unit hunian yang tidak disewakan skarena sejak awal tidak terdapat pada perencanaan desain. Oleh karena itu dibutuhkan pemanfaatan ruang yang fungsional pada lahan yang terbatas.
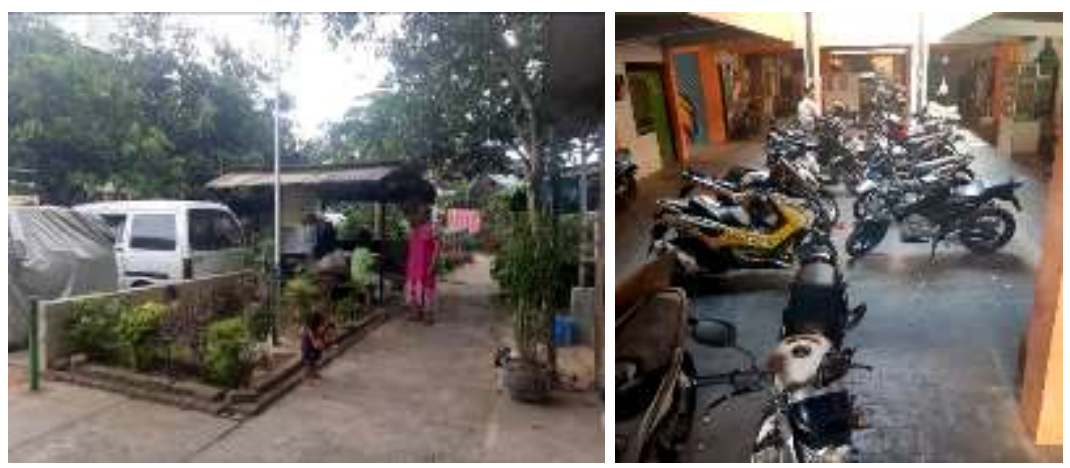

Gambar 6.

Fasilitas RTH dan Area Parkir pada Rumah Susun Muharto, Kota Malang Sumber: Dokumentasi penulis, 2019
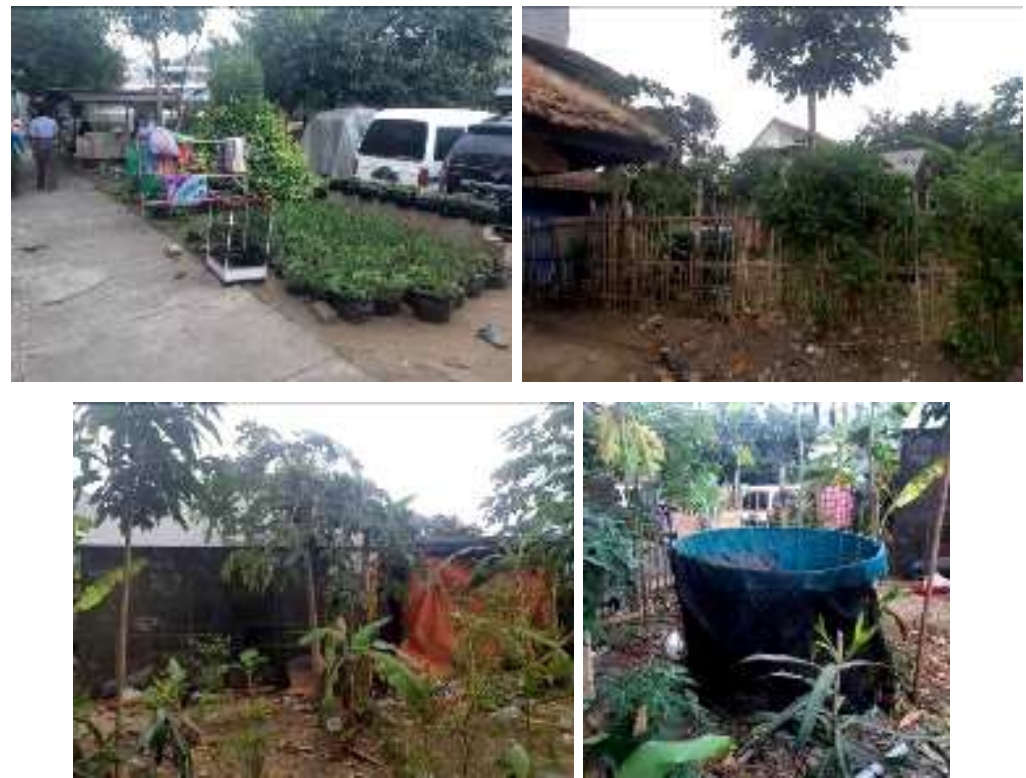

Gambar 7.

Ruang Terbuka Hijau pada Rumah Susun Muharto, Kota Malang Sumber: Dokumentasi penulis, 2019 
Infrastruktur tapak, baik untuk kendaraan dan pejalan kaki telah terwadahi cukup baik pada Rusunawa buring 1 dan 2, Kota Malang; sementara pada Rumah Susun Muharto diperlukan infrastrukur tapak yang lebih layak guna agar dapat meningkatkan kenyamanan pengguna pada lingkungan unit hunian. Kebijakan pengelola rumah susun dalam efektivitas penggunaan jumlah kendaraan bagi penghuni juga perlu dibuat agar lingkungan bangunan semakin sehat, aman, dan nyaman bagi pengguna sehingga berdampak positif terhadap iklim mikro dan makro kawasan.

Fasilitas ruang terbuka seperti area bermain anak dan area olahraga juga belum terwadahi dengan baik pada Rumah Susun Muharto. Perencanaan desain lansekap tapak pada Blok A dan Blok B Rumah Susun Muharto yang terwadahi dan terintegrasi dengan baik dan layak guna diharapkan dapat memberikan dampak positif dalam peningkatan kualitas hidup penghuni rumah susun dan turut berperan dalam mengurangi dampak heat island lokal.

\section{b. Efisiensi energi}

Pramitasari, P. H. (2018) menjabarkan bahwa temperatur udara pada ruang dalam unit hunian Rusunawa Buring 1 dan 2 lebih dari $26{ }^{\circ} \mathrm{C}$ dengan Kelembaban udara relatif $(\mathrm{RH})$ pada unit hunian Rusunawa Buring 1 dan II lebih dari $70 \%$ sehingga belum memenuhi indikator nyaman termal. Hasil yang sama juga didapatkan pada Rumah Susun Muharto, dimana temperatur udara pada unit hunian melebihi $26{ }^{\circ} \mathrm{C}$ dengan $\mathrm{RH}$ melebihi $70 \%$, dimana menunjukkan unit hunian cenderung panas dan lembab.

Upaya efisiensi energi yang dilakukan pada Rumah Susun Muharto, Rusunawa Buring 1 dan 2, diantaranya pencatatan rutin konsumsi listrik tiap bulan pada unit hunian oleh pihak pengelola rumah susun; efektivitas penggunaan lampu sesuai kebutuhan; pemanfaatan gas untuk kegiatan memasak; serta efisiensi penggunaan sistem utilitas bangunan, seperti tidak terdapat AC maupun optimasi tangga sebagai sarana transportasi vertikal tanpa menggunakan lift, khususnya pada Rusunawa Buring 1 dan 2 yang berjumlah lima (5) lantai.

Sementara itu, pemanfaatan alat elektronik berlabel "hemat energi", penggunaan fitur otomatisasi sistem pencahayaan buatan pada zonasi fungsi publik atau zona servis untuk penghematan konsumsi energi listrik, upaya desain fasade bangunan, baik proporsi bukaan terhadap dinding, insulasi, maupun penggunaan material yang ramah lingkungan dan dapat mereduksi panas matahari menuju dalam bangunan, penggunaan pembangkit listrik alternatif sebagai sumber energi listrik terbarukan yang lebih rendah emisi belum dioptimalkan pada rumah susun ini. Audit energi juga dibutuhkan sebagai sistem kontrol operasional dan pemeliharaan energi listrik pada rumah susun. 


\section{Efisiensi air}

Biaya operasional air bersih pada Rusunawa Buring 2 lebih tinggi dibandingkan Rusunawa Buring 1, sedangkan penggunaan galon air minum pada Rusunawa tersebut cenderung stabil bergantung karakteristik penghuni (Pramitasari, P. H. 2018).

Efisiensi penggunaan air yang dilakukan pada objek studi, diantaranya penghematan konsumsi air siap minum dan siap pakai (untuk kebutuhan mandi, cuci, dan kakus - MCK), serta pencatatan rutin konsumsi penggunaan air setiap bulan.

Upaya efisiensi air dapat dioptimalkan lagi melalui upaya penerapan sistem monitoring manajemen air berjangka waktu tertentu, sistem kontrol penggunaan, pemeriksaan, dan pemeliharaan sistem plumbing secara berkala, sistem kontrol kualitas sumber air bersih, pemanfaatan air hujan sebagai sumber air alternatif, pemanfaatan air daur ulang untuk sumber irigasi lansekap, pengelolaan air limbah hingga aman untuk lingkungan, penggunaan air portable untuk kebutuhan air minum, pengurangan pemanfaatan sumur dalam terhadap konsumsi air keseluruhan, serta penggunaan kran air dengan fitur auto stop pada area publik ketiga objek studi.

\section{d. Efisiensi material}

Pemanfaatan material ramah lingkungan belum sepenuhnya diterapkan pada ketiga objek studi, dimana penggunaan material eksisting tidak sepenuhnya produksi lokal ataupun regional dan bersertifikat ISO/ SNI/ ecolabel, belum optimalnya penggunaan material pre fabrikasi dan pemanfaatan material reduce, reuse, dan recycle untuk mengurangi sampah konstruksi, serta belum adanya manajemen pengelolaan sampah berdasarkan pemisahan sampah organik, anorganik, maupun limbah berbahaya (B3).

e. Kenyamanan dan kesehatan ruang dalam

Sirkulasi udara bersih dan ventilasi pada tiap ruang unit hunian di ketiga objek studi belum memenuhi indikator nyaman termal. Pada unit hunian Rumah Susun Muharto, ruang tidur cenderung gelap dan lembab karena tidak terdapat jendela, ruang makan dan balkon juga juga lebih lembab dimanfaatkan menjadi dapur sekaligus area jemur pada beberapa unit hunian sehingga kebutuhan laju udara ventilasi yang memenuhi kesehatan dan kenyamanan termal dalam ruang belum terpelihara secara optimal sebagai upaya konservasi energi.

Optimasi peningkatan kesehatan, kelayakan, dan kenyamanan dalam ruang pada objek studi dapat dilakukan melalui peningkatan pencahayaan alami minimal $50 \%$ dari luasan unit hunian untuk mengurangi penggunaan 
lampu di siang hari dan memenuhi tingkat iluminasi yang nyaman visual di setiap ruang, pengurangan aktivitas merokok dalam ruangan, penggunaan material interior dengan emisi rendah dan penggunaan cat dengan kadar Volatile Organic Compounds (VOC) rendah agar tidak mencemari udara dan membahayakan kesehatan, pengontrolan sistem akustik dari penggunaan insulasi material, desain tata ruang, maupun peralatan listrik dan sistem plumbing agar memberikan kenyamanan dari gangguan suara di luar ruangan, serta rutin melakukan survei kenyamanan pengguna terkait suhu udara, kenyamanan suara, tingkat pencahayaan ruang, kebersihan gedung, serta keberadaan hama pengganggu pada rumah susun. Rasio panjang dan lebar bangunan semakin pipih dan memanjang, maka bangunan tersebut semakin sehat karena mengoptimalkan pencahayaan dan penghawaan alami.

\section{f. Manajemen lingkungan bangunan}

Optimasi efektivitas manajemen lingkungan bangunan pada objek studi dapat didapatkan melalui penetapan standar operasional prosedur dan pengecekan sistem operasional dan pemeliharaan sistem plumbing dan kualitas air, sistem mekanikal dan elektrikal, pemeliharaan interior dan eksterior, dan pengelolaan sampah secara berkala.

Inovasi peningkatan kualitas bangunan juga dapat dilakukan melalui pendekatan manajemen, seperti upaya mendorong perubahan pola perilaku pengguna, serta inovasi dalam desain dan teknologi agar tercipta desain dan konstruksi berkelanjutan.

Aktivitas ramah lingkungan juga telah dilakukan oleh beberapa penghuni rumah susun, seperti penghijauan pada area koridor dimana dibutuhkan sebagai bentuk peningkatan kepedulian lingkungan dan keberlanjutan kawasan sekitar sehingga penghuni rumah susun semakin nyaman dan betah tinggal pada unit hunian.

\section{KESIMPULAN}

Desain bangunan Rumah Susun Muharto, Rusunawa Buring 1 dan 2, Kota Malang belum memenuhi kriteria bangunan hijau. Berbagai upaya pendekatan desain bangunan hemat energi telah diupayakan meskipun belum optimal dalam pemenuhan desain bangunan hijau. Pendekatan desain bangunan hijau pada objek studi diperlukan strategi perencanaan tapak, desain, pembangunan, operasional, pemeliharaan, hingga pembongkaran rumah susun yang terkonsep dengan jelas, terstruktur, dan solutif. 
Aspek-aspek yang menjadi perhatian utama dalam menerapkan karakteristik desain bangunan hijau pada rumah susun umum di daerah beriklim tropis lembab, diantaranya:

a. Efisiensi pemilihan dan perencanaan desain tapak

Aturan atau kebijakan manajemen tapak dari pengelola rumah susun setempat terkait pengurangan penggunaan kendaraan bermotor, pemenuhan kebutuhan fasilitas sarana dan prasarana rumah susun sesuai standar yang telah ditetapkan Pemerintah, pengelolaan desain lansekap tapak yang ramah lingkungan dan memfasilitasi bagi para diffable, serta optimasi ruang terbuka hijau dan pemanfaatan koridor sebagai area penghijauan sebagai upaya peningkatan kualitas hidup penghuni rumah susun.

b. Efisiensi energi listrik dan gas

Aturan atau kebijakan manajemen energi rumah susun oleh pemerintah dan pengelola setempat, efisiensi penggunaan peralatan elektronik hamat energi dan/ atau fitur otomatisasi, pemanfaatan material hemat energi dan nyaman termal, sistem kontrol dan monitoring energi secara rutin dan berkala, sistem operasional dan pemeliharaan sumber energi, serta penggunaan sumber energi terbarukan dan rendah emisi energi.

c. Efisiensi penggunaan air bersih, air limbah, dan air hujan

Kebijakan manajemen air; sistem kontrol dan monitoring sistem manajemen air dan plumbing, serta kualitas sumber air bersih secara periodik; efisiensi konsumsi air minum dan air siap pakai untuk MCK; pemanfaatan air hujan sebagai sumber air alternatif; pengelolaan air daur ulang dan air limbah sebagai sumber irigasi lansekap; pengurangan sumur dalam sebagai sumber air bersih keseluruhan; serta penggunaan kran air fitur auto-stop pada area publik.

d. Efisiensi penggunaan material ramah lingkungan

Pemanfaatan material ramah lingkungan; optimasi material produksi lokal atau regional dan berlabel $\mathrm{SNI} / \mathrm{ISO}$ / ecolabel; optimasi pemanfaatan material pre fabrikasi dan material reduce, reuse, recycle; manajemen pengelolaan sampah melalui pemisahan kategori sampah organik, anorganik, dan limbah berbahaya (B3).

e. Optimasi kenyamanan dan kesehatan ruang dalam

Optimasi penggunaan pencahayaan alami minimal $50 \%$ dari luas unit hunian; pengurangan atau larangan aktivitas merokok di dalam ruang; penggunaan material interior rendah emisi; penggunaan cat rendah 
Volatile Organic Compounds (VOC); penggunaan insulasi material serta perletakan dan penggunaan jenis alat listrik dan sistem plumbing untuk pengontrolan sistem akustik; desain tata ruang yang sehat dan nyaman bagi pengguna, dimana semakin pipih rasio panjang dan lebar bangunan dlam satu massa, maka pencahayaan alami, sirkulasi dan ventilasi udara semakin baik; peningkatan layanan kualitas rumah susun melalui survei kenyamanan pengguna terkait kenyamanan suara, suhu udara, pencahayaan dan penghawaan ruang, keberadaan hama, serta kebersihan gedung pada rumah susun.

f. Efisiensi sistem kontrol (manajemen) lingkungan bangunan

Penetapan standar operasional prosedur dan manajemen kontrol sistem operasional serta sistem pemeliharaan sistem plumbing dan kualitas air, sistem mekanikal dan elektrikal; perawatan ruang dalam dan ruang luar; pengelolaan sampah secara periodik; inovasi desain dan teknologi; pendekatan manajemen perilaku pengguna "sehat dan hemat energi"; serta adanya program kegiatan atau aktivitas penghuni dan pengelola rumah susun secara konkret sebagai bentuk kepedulian terhadap lingkungan dan keberlanjutan kawasan.

Penerapan konsep bangunan hijau pada bangunan rumah susun diharapkan dapat terwujud agar tercipta model bangunan rumah susun yang sehat, nyaman, dan efisien energi bagi para pengguna.

Penelitian ini tentu masih terdapat beberapa kekurangan dan keterbatasan, diantaranya keterbatasan jenis dan jumlah alat ukur penelitian. Rekomendasi penelitian selanjutnya dapat dikembangkan pada objek studi lain, seperti bangunan rumah tinggal, apartemen, kantor, ataupun bangunan komersial.

\section{DAFTAR PUSTAKA}

Green Building Council Indonesia. (2016). Greenship Rating Tools Untuk Gedung Terbangun Versi 1.1.

Pramitasari, P. H. (2018): Karakteristik Konsumsi Energi Bangunan pada Rumah Susun Umum di Malang, Jurnal PAWON, 2 (2), 73-86.

Sudarwani, M. M. (2012): Penerapan Green Architecture dan Green Building Sebagai Upaya Pencapaian Sustainable Architecture. Dinamika Sains, 10 (24).

Tanuwidjaja, G. (2011). Desain Arsitektur Berkelanjutan di Indonesia: Hijau Rumahku Hijau Negeriku. 